\title{
PROFITABILITY OF SMALL SCALE BROILER PRODUCTION IN SOME SELECTED AREAS OF MYMENSINGH
}

\author{
K. M. A. Al-Mamun Rana ${ }^{1}$, M. S. Rahman ${ }^{2}$ and M. N. Sattar ${ }^{3}$ \\ Department of Agricultural Economics, Bangladesh Agricultural University \\ Mymensingh-2202, Bangladesh
}

\begin{abstract}
This study aimed to determine the cost, return, and profitability of broiler production in some selected areas of Mymensingh district. It was mainly based on primary data which were collected through face to face interview from the respondents of broiler production during the month of December, 2011. Selected samples consisted of 30 broiler farm owners selected by using purposive sampling technique. For the analysis of data, tabular and production function techniques were used. This study estimated the average cost of raising broiler to be Tk. 8,35,910.65 per farm per year. It was found that the variable cost per farm per year stood at Tk. 8,23,735.93 which accounted for 98.54 percent of total cost. The total fixed cost per farm per year accounted to Tk. 14,041.66. It is evident from the study that the gross return per farm per year stood at Tk. 10,78,022.39. The net return per farm per year was calculated at Tk. 2,42,111.47. The findings revealed that broiler production was a profitable enterprise. Cobb-Douglas production function was also applied to explore the specific effect of the factors on broiler production. It was observed that most of the included variables had significant impact on broiler production. Out of six variables included in the regression, four variables (i.e., feed cost, cost of day-old chick, labour cost and litter cost) had significant positive impact on return. This study also identified some problems in the production of broiler in the study area. Finally, based on the findings of the study, some recommendations were made for the development of broiler production in Bangladesh.
\end{abstract}

Key Words: Broiler production, Profitability

\section{INTRODUCTION}

Bangladesh is a densely populated developing country and its economy is very much dependent on agriculture. Poultry is a part of agricultural farming system in Bangladesh and broiler is one of the main products of poultry farming. Even though raising poultry birds is mostly a subsistence practice in Bangladesh, broiler is mainly commercially produced in Bangladesh. The contribution of broiler production is vital to the national

1 Ex MBA student of Bangladesh Open University, Gazipur

2\&3 Associate Professor and Lecturer of Agricultural Economics, Bangladesh Agricultural University, Mymensingh-2202, Bangladesh 
economy in case of generating employment opportunity, additional income for households and improving the nutritional level of the people. About 2.58 percent of GDP came from animal farming during the 2010/11 financial year (MoF 2012). In addition, broiler is an excellent source of protein and nutrients which are essential for health and growth of the human body.

The poultry sector has emerged as a flourishing and promising commercial sector in Bangladesh during the recent years. The poultry sector registered a per holding increase of 38.8 percent and per capita increase of 64.8 percent for the period between 1983/84 and 2005 (Planning Commission 2011). In fact, there has been a silent revolution in the poultry sector during the last decade. During the 2000/01-2008/09 decade poultry population registered a growth of over 5 per cent (ibid.). It is one of the fastest growing sectors with bright future and plays a crucial role in supplying nutritious food and generating income. It is recognized as a profitable business by many people and getting popularity day by day as employment opportunity is being created among people. As a developing country, unemployment, inadequate nutrition and poverty, scarcity of arable land are the major problems in Bangladesh. About 31 percent of the population in Bangladesh lives below the absolute poverty line and the number of landless people has been increasing by 3.4 percent per annum (BBS, 2009). About 50 percent of the children are born underweight and 52 percent of the mothers suffer from nutrition deficiency (BBS 2007). The per capita intake of poultry meat in Bangladesh is only 11.2 grams per day (HIES 2011) compared to a standard requirement of 36 grams per day (Ahmed and Islam 1985). Commercial broiler farming serves as ready source of income among the poor people when need money and creates the employment opportunity for educated unemployed youth and also for women. It has been acting as an important tool for reducing the migration from rural poor people to the urban areas. Millions of rural women are involved in poultry rearing under the poverty alleviation program of direct Non-Government Organizations (NGOs) and Department of Livestock Service (DLS) under its packages program.

The climate of Bangladesh is suitable for broiler farming, so the broiler birds can be raised easily to fulfill daily requirements of nutrient value. Broiler has shorter life cycle and its production requires less capital compared to other meat producing animals. The demand of broiler meat has been increasing day by day. The majority of the people, irrespective of caste and religion, prefer chicken. As a result, the prices of broiler have gone up over the years. Observing the situation of high price and demand in home market, a tendency to establish a small scale commercial farm has grown among people both in rural and urban areas. Therefore, poultry farming is shaping up as an industry. Many NGOs have come forward to give them assistance for setting up small poultry farm. However, the number of poultry farm is not increasing as rapidly as it was expected because of many reasons.

Some socioeconomic studies have so far been conducted on broiler farming in different areas of Bangladesh. Previously, studies have been conducted, among others, by Ahmed (2001); Tohura (2004); Akbar and Hossain (2005); Akram (2006); Rahman (2007); Akhter (2008); Sultana (2009) and Piasa (2011) etc researchers on cost, return and profitability of boiler farming in selected areas of Tangail, Rangpur, Kishoreganj, Gazipur and 
Mymensingh districts. All of the studies found broiler production to be profitable, although the level of profit varied among the studies.

The above reviews clearly indicate that only a few studies have been conducted on broiler farming. This study expects to provide useful and important information to broiler producers, consumers and other concerned people of Bangladesh. This research was conducted using latest data regarding production and thus it will help both the researchers and the farmers in Bangladesh. The findings of the study is also expected to be helpful to the broiler farmers and policy makers for taking appropriate decision regarding further expansion of commercial broiler production. The results of this study will provide some basic information to policy makers, production economics specialists, extension workers and enable them to formulate policies regarding effective production plan in case of broiler farming. The study will also provide information to the researchers, who are interested in conducting studies in future.

This is a micro level study on broiler farming and marketing at some selected areas of Mymensingh district. The specific objectives of the study are as follows:

1. To determine the cost, return and profitability of small scale broiler farming;

2. To estimate the factors affecting on financial return of broiler production; and

3. To identify the problems faced by broiler farm owners, and to suggest measure for improving the situation.

\section{METHODOLOGY}

This study was based on field survey of farmers who practiced broiler farming. The survey method was chosen in the present study, because of its various advantages. Considering the objectives of the study and limitations of the research work with respect to time, manpower and other facilities, some areas of Fulbaria and Sadar Upazilas under Mymensingh district were purposively selected. Recently, a large number of commercial broiler farms have been developed in the selected areas. A purposive sampling technique was followed in this study. In total 30 broiler farms were selected for the present study. Data were collected during the month of December, 2011 through face to face interview with the respondents. All of the collected primary data were edited coded, tabulated, summarized and processed for analysis. Finally, relevant tables were prepared in accordance with the objectives of the study.

\section{Analytical techniques}

The following techniques were used for analyzing the data:

\section{Descriptive statistics}

Descriptive statistics like sum, average, percentage, etc. were used to show the performance of broiler fanning. Profitability analysis was done on the basis of variable cost, fixed cost, etc. The following profitability equation was applied in the study. 
$\mathrm{II}=\mathrm{P}_{\mathrm{b}} \mathrm{Q}_{\mathrm{b}}+\mathrm{P}_{1} \mathrm{Q}_{1}-\sum_{\mathrm{i}=1}^{\mathrm{n}}\left(\mathrm{Px}_{\mathrm{i}} \mathrm{X}_{\mathrm{i}}\right)-\mathrm{TFC}$

Where,

$\Pi$ = Profit (Tk./year/farm);

$\mathrm{P}_{\mathrm{b}}=$ Per unit price of live broiler $(\mathrm{Tk} . / \mathrm{kg})$;

$\mathrm{Q}_{\mathrm{b}}=$ Quantity of live broiler $(\mathrm{kg} /$ year $/$ farm $)$

$\mathrm{P}_{1}=$ Per unit price of used litter and extra (Tk. / kg);

$\mathrm{Q}_{1}=$ Quantity of waste litter (kg/year/farm);

$\mathrm{P}_{\mathrm{xi}}=$ Per unit price of $\mathrm{i}^{\text {th }}$ (variables) inputs used in the broiler farm $(\mathrm{Tk} . / \mathrm{kg})$;

$X_{i}=$ Quantity of $i^{\text {th }}$ (variables) inputs used in $\mathrm{kg}$; and

$\mathrm{TFC}=$ Total fixed cost involved in broiler farm (Tk./year/farm).

\section{Regression analysis}

The Cobb-Douglas production function was used in the present study to examine the effects of the independent variables on gross return in broiler production. The CobbDouglas production function was chosen as this model provides a compromise between (i) adequate fit of the data, (ii) computation feasibility, (iii) sufficient degrees of freedom to allow for statistical testing. In linear form, the model took the following shape:

$\operatorname{In} Y=\operatorname{In} a+b_{1} \operatorname{In} X_{1}+b_{2} \operatorname{In} X_{2}+b_{3} \operatorname{In} X_{3}+b_{4} \operatorname{In} X_{4}+b_{5} \operatorname{In} X_{5}+b_{6} \operatorname{In} X_{6}+U_{i}$

Where,

$\mathrm{Y}=$ Gross return for the ith farm (Tk./yr.);

$\mathrm{a}=$ Constant or intercept value;

$\mathrm{X}_{\mathrm{l}}=$ Cost of feed for $\mathrm{i}^{\text {th }}$ farm (Tk./yr.);

$\mathrm{X}_{2}=$ Cost of day-old chicks for $\mathrm{i}^{\text {th }}$ farm (Tk./yr.);

$\mathrm{X}_{3}=$ Cost of hired labour for $\mathrm{i}^{\text {th }}$ farm (Tk./yr.);

$\mathrm{X}_{4}=$ Veterinary expanses for $\mathrm{i}^{\text {th }}$ farm (Tk./yr.);

$\mathrm{X}_{5}=$ Cost of electricity for $\mathrm{i}^{\text {th }}$ farm (Tk./yr.);

$\mathrm{X}_{6}=$ Cost of litter for $\mathrm{i}^{\text {th }}$ farm (Tk./yr.);

$\mathrm{U}=$ Error term;

$\mathrm{i}=1,2,3$, 60 ;

$b_{1}, b_{2}, b_{3}, b_{4}, b_{5}, b_{6}=$ Regression co-efficient of respective variables; and

In = Natural log.

\section{RESULTS AND DISCUSSION}

In this section, the costs, returns and profitability of raising broiler birds is estimated. In estimating cost of rearing broiler birds total costs per farm per year both variable and fixed costs were considered. Variable costs were cost for variable inputs like day-old chick, feed, veterinary expenses, hired labour, family labour, litter costs, electricity cost and transportation cost. On the other hand, fixed cost included housing cost, tools and equipment, land use cost etc. On the returns side, gross return, gross margin, net return, return per taka invested on total cost were estimated. On average eight batches of birds 
were reared annually per farm. The item wise costs and return of broiler production are mentioned here.

Cost of broiler production: In the present study, the total cost of broiler production was estimated at Tk. 835910.65 per farm per year. Table 1 represents the total costs of broiler production. Total variable cost and total fixed cost were Tk. 814615.99 and Tk. 21294.66; which were 97.45 and 2.54 percent of total cost, respectively.

Table 1. Total costs of broiler production per farm per year

\begin{tabular}{|c|c|c|c|c|c|}
\hline \multirow[t]{2}{*}{ Cost items } & \multirow[t]{2}{*}{ Unit } & \multirow{2}{*}{$\begin{array}{l}\text { Unit } \\
\text { Price }\end{array}$} & \multicolumn{2}{|c|}{ Per farm } & \multirow{2}{*}{$\begin{array}{c}\text { As a percentage } \\
\text { of total cost }\end{array}$} \\
\hline & & & Quantity & Total cost (Tk.) & \\
\hline A. Variable cost & & & & $8,23,735.93$ & 98.54 \\
\hline a) Feed cost & $\mathrm{Kg}$ & 36.4 & 15640 & $5,69,173.3$ & 68.09 \\
\hline b) Day-old chick cost & No. & 21.33 & 7253 & $1,54,693.3$ & 18.51 \\
\hline c) Hired labour & Man-day & & & 24,400 & 2.92 \\
\hline d) Family labour & Man-day & & & 9,120 & 1.09 \\
\hline e)Veterinary cost & Tk. & & & $43,866.67$ & 5.25 \\
\hline f) Electricity cost & Tk. & & & $2,906.66$ & 0.35 \\
\hline g) Litter cost & Tk. & $123.5 /$ bag & 120.26 & $14,829.33$ & 1.77 \\
\hline h) Transportation cost & Tk. & & & $4,746.67$ & 0.57 \\
\hline B. Fixed cost & & & & $14,041.66$ & 1.68 \\
\hline i) Housing cost & Tk & & & 8,850 & 1.06 \\
\hline j) Tools \& equipment cost & Tk. & & & 2,425 & 0.29 \\
\hline k) Land use cost & Tk. & & & $2,766.66$ & 0.33 \\
\hline Total costs $(\mathrm{A}+\mathrm{B})$ & Tk. & & & $8,35,910.65$ & 100.00 \\
\hline
\end{tabular}

Source: Field Survey, 2011

Returns from broiler production: Gross return was determined by adding income earned from sale of live broiler, used litter and excreta (feed sack). Table 2 shows that on an average, price per kilogram of live broiler received by the farm owners was Tk. 102.26. On the other hand, prices of per feed sack were 10.66 and they also sold used litter. The gross returns per farm per year for were Tk. 10,78,022.39.

Profit from broiler production: Gross margin analysis is applied to look into the profitability of broiler. It is evident from table that gross margins per farms per year was Tk. 2,63,406. Net return on total cost was obtained by deducting all the costs from the gross return. Table 3 shows that net return for broiler farm per year stood at Tk 242112. Benefit-cost ratio (BCR) implies return per taka invested. Table 3 shows that on an average, the benefit-cost ratios of broiler farming were 1.323 on variable cost basis, and 
1.289 on total cost basis. The figures imply that broiler farming generates 32 percent profit on variable cost basis and 28 percent profit on total cost basis. Thus it emerges from this research that broiler farming is a profitable enterprise for the farmers under the study.

Table 2. Gross return from broiler production per farm per year

\begin{tabular}{l|c|c|c|c}
\hline \multicolumn{1}{c|}{ Items } & Unit & \multirow{2}{*}{ Unit price } & \multicolumn{2}{c}{ Per farm/year } \\
\cline { 4 - 5 } & & & Quantity $(\mathrm{Kg})$ & Value (Tk.) \\
\hline 1. Live broiler & $\mathrm{Kg}$ & 102.26 & 10466.66 & 1070813.33 \\
2. Feed sack & Piece & 10.66 & 334 & 3555.733 \\
3. Used litter & & & & 3653.33 \\
Gross return (1+2+3) & & & - & 1078022.393 \\
\hline
\end{tabular}

Source: Field Survey, 2011

Table 3. Cost, return and benefit-cost ratio per broiler farm per year

\begin{tabular}{lccc}
\hline \multicolumn{1}{c}{ Cost \& Returns } & Unit & Per farm/ Year \\
\hline A. Gross return & Tk. & 1078022.39 \\
B. Total variable cost & Tk. & $8,23,735.93$ \\
C. Fixed cost & Tk. & $14,041.66$ \\
C. Total cost & Tk. & $8,35,910.65$ \\
D. Gross margin (A-B) & Tk. & $2,54,286.46$ \\
E. Net return (A-C) & Tk. & 242111.47 \\
F. Return per taka invested (Variable cost basis) A $\div$ B & - & 1.323 \\
G. Return per taka invested (Total cost basis) A $\div$ C & - & 1.289 \\
\hline
\end{tabular}

Source: Field Survey, 2011

Regression analysis: The effects of some important variable inputs on gross return of broiler production were analyzed through the Cobb-Douglas production function. It can be seen from Table 4 that the regression co-efficient of feed and day-old chick cost were positive. These were significant at 1 percent level. The regression coefficient indicate that 1 percent increase in feed cost and day old chick, keeping other factors constant, would result in an increase in the gross return by 0.67 and 0.45 percent in broiler farms respectively.

The regression co-efficient of labour cost $\left(\mathrm{X}_{3}\right)$ was negative and significant at 10 percent level. The regression co-efficient indicate that 1 percent increase in the labour cost, remaining other factors constant, would result in 0.17 percent decrease in the gross return for broiler farms. 
The regression co-efficient of litter cost $\left(\mathrm{X}_{6}\right)$ was positive and significant at 5 percent level. The regression co-efficient of broiler farms imply that 1 percent increase in litter cost, keeping other costs constant, would result in an increase of gross returns by 0.19 percent.

Table 4. Estimated values of co-efficient and related statistics of Cobb-Douglas production function

\begin{tabular}{lcccc}
\hline \multicolumn{1}{c|}{ Explanatory variables } & Co-efficient & Standard error & T-value \\
\hline Intercept & 0.871 & 0.97 & 0.89 \\
Feed $\left(\mathrm{X}_{1}\right)$ & $0.67^{* * *}$ & 0.12 & 5.38 \\
Day-old chick $\left(\mathrm{X}_{2}\right)$ & $0.45^{* * *}$ & 0.10 & 4.24 \\
Labour cost $\left(\mathrm{X}_{3}\right)$ & $-0.173^{*}$ & 0.09 & -1.79 \\
Veterinary cost $\left(\mathrm{X}_{4}\right)$ & -0.022 & 0.05 & -0.42 \\
Electricity $\left(\mathrm{X}_{5}\right)$ & 0.060 & 0.06 & 0.91 \\
Litter $\left(\mathrm{X}_{6}\right)$ & $0.191^{* *}$ & 0.08 & 2.34 \\
$\mathrm{R}^{2}$ & 0.978 & & \\
Adjusted $\mathrm{R}^{2}$ & 0.973 & & \\
F-value & $17.265^{* * *}$ & & \\
Returns to scale & 1.17 & & \\
\hline
\end{tabular}

*** Indicates significance at 1 percent level; **Indicate significance at 5 percent level; ${ }^{*}$ Indicate significance at 10 percent level

The co-efficient veterinary expenses and electricity were insignificant according to the regression analysis.

The co-efficient of multiple determination $\left(\mathrm{R}^{2}\right)$ was 0.97 . It indicates that 97 percent of the variations in the gross returns were explained by the independent variables included in the model. The F-value (17.26) of the equation of broiler farms was significant at 1 percent level of confidence; imply good fit of the model.

Returns to scale: Returns to scale of broiler farms were computed by adding co-efficient of regression of broiler farms. The sum total of all the production co-efficient of the equation for broiler production was 1.17. This indicates that the production exhibited increasing returns to scale.

\section{PROBLEMS IN BROILER FARMING}

The major problems identifies by the broiler farmers under the study were high price of day old chicks, high price of feed, insufficient growth, shortage of electricity, lack of credit, 
low price of broiler, outbreak of diseases, pollution of the environment etc. The problems mentioned by respondents are mentioned and ranked in Table 5 .

Table 5. Problems faced by the broiler farm owners

\begin{tabular}{|c|c|c|c|}
\hline Problems & $\begin{array}{c}\text { Number of reporting } \\
\text { farmers (Total number }=30 \text { ) }\end{array}$ & $\begin{array}{c}\text { Percentage } \\
(\%)\end{array}$ & Ranking \\
\hline \multicolumn{4}{|l|}{ A. Production problems: } \\
\hline a) High price of day-old chick & 28 & 95 & 1 \\
\hline b) Higher price of feed & 28 & 92 & 2 \\
\hline c) Growth problem & 21 & 88 & 3 \\
\hline d) Lack of credit & 24 & 80 & 4 \\
\hline e) Electricity problem & 17 & 58 & 5 \\
\hline f) Lack of capital & 17 & 58 & 5 \\
\hline g) Non-availability of day-old chicks & 16 & 53 & 6 \\
\hline h) Lack of training facilities & 14 & 47 & 7 \\
\hline i) Uncertainty of profit & 11 & 37 & 8 \\
\hline \multicolumn{4}{|l|}{ B. Marketing problems: } \\
\hline a) Lower price of broiler & 27 & 90 & 1 \\
\hline b) Late payment & 12 & 42 & 2 \\
\hline c) Rumor & 12 & 40 & 3 \\
\hline \multicolumn{4}{|l|}{ C. Social and natural problems: } \\
\hline a) Outbreak of diseases & 22 & 75 & 1 \\
\hline b) Pollution of environment & 18 & 62 & 2 \\
\hline c) Predator animals & 2 & 7 & 3 \\
\hline
\end{tabular}

Source: Field Survey, 2011

\section{CONCLUSION AND RECOMMENDATIONS}

The results show that broiler production was profitable in the study area. So, there is a wider scope for the development of broiler farming and trading in this country. However, the broiler farmers are facing some problems. If government give emphasize on poultry sector, prepare proper policy, monitor the market and encourage the farmer, soon poultry rearing will be a blooming agricultural sector.

To overcome the difficulties of broiler keeping and to make the business of broiler keeping more profitable in the country, the following recommendations are put forward for the improvement of existing production and trading of live broiler.

1. The government should control the high price of feed and day-old chicks. They should give incentives to the private feed manufacturing factories and hatcheries as it can be helpful to reduce the high price of feed and day-old chicks;

2. Government and private research centers should try to develop improved breed for higher production;

3. Price stabilization and/or floor price schemes should be chalked out to make sure that 
broiler producers receive the minimum level of profits; and

4. The government should increase veterinary services by supplying necessary vaccine and medicine at lower price and by establishing new veterinary care centers.

\section{REFERENCES}

Ahmed, M. F. U. 2001. A Comparative Economic Analysis of Broiler Production under Proshika Supervision and Farmers Own Management in Some Selected Areas of Tangail district. An MS Thesis, for the Department of Agricultural Economics, Bangladesh Agricultural University, Mymensingh.

Akbar, M. A. and M. I. Hossain. 2005. Impact of Private Poultry Enterprise on Rural Employment and Income Generation in Kishorgonj District. Research Report Submitted in BAURES, Mymensingh.

Akhter, S. 2008. Broiler Farming Under AFTAB Bahumikhi Farm Limited Supervision and Farmers Own Management: A Comparative Efficiency Analysis. An M. S. Thesis, for the Department of Agricultural Economics, Bangladesh Agricultural University, Mymensingh.

Akram, H. 2006. An Economic Analysis of Broiler Production in A Selected Area of Mymensingh District. An M. S. Thesis, for the Department of Agricultural Economics, Bangladesh Agricultural University, Mymensingh.

BBS. 2009. Statistical Year Book of Bangladesh. Bangladesh Bureau of Statistics, Statistical Division, Ministry of Planning, Government of the People's Republic of Bangladesh, Dhaka.

HIES. 2011. Report of the Household Income and Expenditure Survey 2010. Bangladesh Bureau of Statistics, Ministry of Planning, Government of the People's Republic of Bangladesh, Dhaka.

MoF. 2012. Bangladesh Economic Review 2012. Economic Adviser's Wing, Finance Division, Ministry of Finance, Government of the People's Republic of Bangladesh, Dhaka.

Piasa, M. M. 2011. An Economic Study on Integrated Fish-Poultry Farming in Some Selected Areas of Mymesningh District. An M. S. Thesis, for the Department of Agricultural Economics, Bangladesh Agricultural University, Mymensingh.

Planning Commission. 2011. Sixth Five Year Plan FY 2011-FY 2015: Accelerating Growth and Reducing Poverty, Part-2: Sectoral Strategies, Programs and Polices. Planning Commission, Ministry of Planning, Government of the People's Republic of Bangladesh.

Rahman, B. 2007. An Economic Analysis of Broiler Production under Contract Farming System in a Selected Area of Bangladesh. An M. S. Thesis, for the Department of Agricultural Economics, Bangladesh Agricultural University, Mymensingh.

Sultana, A. 2009. An Economic Analysis of Broiler Production in Some Selected Areas of Mymensingh. An M. S. Thesis, for the Department of Agricultural Economics, Bangladesh Agricultural University, Mymensingh.

Tohura, S. 2004. Economics of Small-Scale Commercial Broiler Farming in Sadar Upazila of Rangpur District. An M. S. Thesis, for the Department of Agricultural Economics, Bangladesh Agricultural University, Mymensingh. 